\title{
Differences in CSR Disclosure in the Annual Reports of Islamic and Conventional Banks: Evidence from Kuwait
}

\author{
Ghareeb M. Almutairi ${ }^{1}$, Mohammad H. J. Almarri ${ }^{1}$, \& Ahmad S. Alsamhan ${ }^{1}$ \\ 1 Accounting Department, School of Business Studies, Public Authority of Applied Education and Training, \\ Kuwait \\ Correspondence: Mohammad H. J. Almarri, Accounting Department, School of Business Studies, Public \\ Authority of Applied Education and Training, Kuwait. Tel: 965-6506-2221. E-mail: malmarri11@ hotmail.com
}

Received: November 8, 2020

Accepted: November 16, 2020

Online Published: November 30, 2020

doi:10.5539/ass.v16n12p8

URL: https://doi.org/10.5539/ass.v16n12p8

\begin{abstract}
This paper explores the differences in corporate social responsibility disclosure in the annual reports of Islamic and conventional banks operating in Kuwait. A content analysis of the six banks' annual reports from 2007 through 2009 was conducted to examine their corporate social responsibility practices in relation to the marketplace, workplace, community, and environment. The results show that both types of banks made certain social disclosures in the years studied. Interestingly, despite Islamic Sharia calls for and emphasizes ethical business behavior, the Islamic banks studied disclosed less corporate social responsibility information as compared with conventional banks. Furthermore, the corporate social responsibility information disclosed by the Islamic banks declined noticeably over time. The conventional banks, however, increased their disclosures during the financial crisis of 2008. By measuring and comparing the volume of corporate social responsibility information disclosed by the three Islamic banks and the three conventional banks in Kuwait the results of this study contribute to the corporate social responsibility literature.
\end{abstract}

Keywords: corporate social responsibility, reporting, disclosure, Islamic banks

\section{Introduction}

Corporate social responsibility (CSR) and CSR reporting is not a new concept in the accounting literature. A large number of studies have empirically assessed CSR reporting practices around the world. However, the amount of research, which has been focused on CSR reporting practices in the Islamic world in general and Arab countries, in particular has been limited. Following the financial crisis in 2008, the Islamic banking system has received international attention due to its socio-economic role (Rahman et al., 2014; Kamla \& Rammal, 2013; Belal et al., 2011; Aribi \& Gao, 2010; Haniffa \& Hudaib, 2007; Kamla, 2007; Maali et al., 2006). As a result, a growing number of studies have investigated the influence of Islamic values on CSR reporting practices in general and Islamic banks in particular (Kamla \& Rammal, 2013; Belal et al., 2011; Aribi \& Gao, 2010). All of the mentioned papers agreed on the fact that Islamic banks are expected to be more socially responsible than conventional ones.

A review of prior studies reveals that the discussion on CSR reporting from an Islamic perspective does not go beyond the exploration of the extent of the compliance of Islamic banks reporting with Islamic Sharia (i.e. Haniffa \& Hudaib, 2007; Maali et al., 2006). Nevertheless, there are two different types of banks operating in Islamic and Arab countries and these studies (except the work of Aribi \& Gao, 2010) have ignored the exploration of the differences in CSR reporting practices among them. Thus, the primary purpose of the research is to explore the differences in CSR reporting between 2 types of banks by analysing the annual reports of six Kuwaiti banks, 3 Islamic and 3 conventional ones over a three-year period. This purpose will be pursued along three dimensions. First, the study will focus on the two types of banks operating in Kuwait to explore the distinction that can be drawn between the Islamic banks and conventional ones. Second, the study will explore the types of CSR disclosure (substantive, symbolic) which are mostly disclosed by Islamic banks and Conventional ones. Finally, the study will explore the kinds of news (negative, positive) which mostly the two groups of banks release.

Sixteen annual reports from 2007 to 2009, representing six Kuwaiti banks, 3 Islamic and 3 conventional ones, are examined to analyse the CSR reporting practices of banks using content analysis. The results of this study 
show that both the Islamic banks and conventional ones made some CSR disclosure relevant to the marketplace, workplace, and community throughout the three years studied. However, despite Islamic Sharia calls for and emphasizes ethical business behaviour, the Islamic banks disclosed less CSR information as compared with conventional banks. Even during and following the financial crisis in 2008, the Islamic banks did not disclose more CSR information. On the contrary, conventional banks increased their overall CSR information during and following the financial crisis in 2008. Furthermore, the CSR disclosure provided by the Islamic banks declined noticeably over the three years studied.

The findings of this study contribute to the CSR literature by detailing the differences and similarities between Islamic and conventional banks with respect to the volume, the types of CSR information and the kinds of news disclosed by the two groups of banks. Examining CSR reporting from the standpoint of an emerging market such as Kuwait would contribute to a better understanding of social accounting problems. In addition, examining the CSR reporting practices of Islamic banks is likely to provide new insight into the influence of Islam on CSR disclosure. Examining the CSR reporting practices of conventional banks operating in Muslim country would also provide new insight into the influence of Islamic and Arab culture on CSR reporting of conventional banks operating on the western system.

The remainder of this paper is organized as follows: Section 2 briefly reviews the banking sector in Kuwait. Section 3 discusses the concept of social responsibility in Islam and reviews prior theoretical and empirical research on corporate social responsibility. Section 4 describes the data and methodological approach used. Section 5 discusses the empirical results and research findings. Section 6 presents the conclusions.

\section{The Banking Sector in Kuwait}

The Kuwaiti banking system is one of the strongest in the Middle East and North Africa region (Capital Standards, 2011). The strength of the banking system stems from supportive government policies. Currently, there are 22 banks operating in the country, of which 10 are local banks and 12 are international banks (Capital Standards, 2013) .In Kuwait, banks can be divided into two categories: conventional commercial banks and Islamic banks, the latter of which operate according to Islamic Sharia law, whereas the former mainly operate according to Western banking system. The Kuwaiti banking system began in 1941 with the opening of a branch of the British Iranian Imperial Bank. The first Kuwaiti bank was the National Bank of Kuwait (NBK), which was established in 1952. In 1977, Islamic banking began in Kuwait with the establishment of Kuwait Finance House (KFH) (Alkulaib et al., 2013).

\section{Literature Review}

\subsection{Social Responsibility from an Islamic Perspective}

The early seventh century witnessed the beginning of Islam (Brewer \& Salamé, 2009). At that time, the Prophet Mohammed, the first world prophet, and the holy Quran were sent to all humanity, not just the Arab nations. The holy Quran is considered the final scripture until the Day of Judgment. Thus, the Holy Quran deals with diverse facets of human life and includes comprehensive principles applicable to all spheres of life including economic, social, political, and familial (Mawdudi, 1988). In the Islamic context, Islamic Sharia is a set of ethics and values originated from the teachings of the Holy Quran and Prophet Mohammed's Sunnah in all aspects of human life (Sairally, 2006). In Islam, the rights and obligations of individuals and organisations are clearly identified by Islamic Sharia. Therefore, the rights and obligations are unchangeable or subject to personal views (Maali et al., 2006) whereas in western perspective, there is no agreed of who determines the responsibilities and they change over time (Gray et al., 1987).

In the Islamic context, the concept of Khilafah (vicegerent or trustee) defines the people's responsibility to God, the community, and to themselves. This concept was demonstrated by some sayings of Prophet Mohammed. For example, Prophet Mohammed told us that: "The world is green and beautiful and God has appointed you his trustee over it" (Bukhari, 1997). Additionally, the concept of vicegerency has been expressed in the Holy Quran: "I will create a vicegerent on earth" (Quran, 2: 30). People are, thus, the vicegerent of God and are accountable for all their actions to God, and then people will be rewarded or punished in the hereafter according to their actions (Kamla, 2005). In other words, the dual role of man in this life is that, on the one hand, man behaves and acts as a servant of God through worshipping Him and following His laws. On the other hand, man behaves and acts as Khilafah on earth through enforcing Islamic Sharia, protecting the environment and maintaining the peace (Hassan, 1992).

One of the most crucial tools for assuring redistribution of wealth is Zakat (Badawi, 1979). Zakat is one of the five pillars of Islam and it is considered a part of fulfilling social responsibility (Mohammed, 2007). It is a 
religious levy based on wealth and its basic rate is 2.5 percent. It is payable once every year. It is considered a means of purification for all Muslims (Mukhazir et al., 2006) God says, "Take from their wealth so that you might purify and sanctify them" (Quran 9:103). Furthermore, According to this principle of Zakat, Muslims are required to contribute to Islamic society by helping needy people through paying $2.5 \%$ of their wealth yearly. Thus, Zakat is considered one of the main pillars of the economic and financial system Muslim communities (Mukhazir et al., 2006).

Additionally, the principle of truthfulness and honesty in business transactions is considered the cornerstone of notion of business in Islam. According to this principle Muslim businessmen are obligated to disclose all defects in their goods to the buyer. In this regard, Prophet Mohammed said:

The seller and the buyer have the right to keep or return the goods as long as they have not parted or till they part; and if both the parties spoke the truth and described the defects and qualities [of the goods], then they would be blessed in their transaction, and if they told lies or hid something, then the blessings of their transaction would be lost (Bukhari, 1997).

Moreover, In the Islamic context, the principle of fair treatment of workers is that the relationship between employer and the employees should be based on the ground of brotherhood. Prophet Mohammed said that:

Allah has placed those (Workers) under you. Those are your brothers. So, if anyone of you has someone under him, he should feed him out of what he himself eats, clothe him like what he himself puts on, and if that be the case, let him not put so much burden that he is not able to bear, then lend your help (Bukhari, 1997).

Prophet Mohammed also said "A Muslim is a brother of another Muslim: he neither wrongs him, nor leaves him without help, nor humiliates him" (Bukhari, 1997). In Islam mangers are counted as shepherd of the workers and thus they are responsible for providing guidance and vision to their employees in order to maximize their productivity (Lewis, 2001).

\subsection{Previous Studies on CSR Disclosure from an Islamic Perspective}

Corporate social responsibility (CSR) and its disclosure is not a new concept in the accounting literature. A large number of studies have empirically assessed CSR reporting practices around the world. The last two decades have witnessed an increase in the production of CSR reports in developed countries over the world (Bebbington et al., 2008). However, a limited number of research has been focused on developing countries such as Arab and Islamic markets (Rahman et al., 2014; Kamla \& Rammal, 2013; Belal et al., 2011; Aribi \& Gao, 2010; Haniffa \& Hudaib, 2007; Kamla, 2007; Maali et al., 2006). After the financial crisis in 2008, Islamic banking and finance has received international attention and then a growing number of studies have focused on the differences between Islamic banks and conventional ones regarding their social role and CSR reporting. Additionally, other researchers have examined the influence of Islam on CSR reporting and highlighted the extent of adherence of Islamic banks to Islamic Sharia. All of the mentioned papers agreed on a single point that Islamic banks are expected to be more socially responsible than conventional ones.

In Islamic banking context, the work of Rahman et al. (2014) is the latest attempt to explore the concept of CSR reporting from Islamic perspective. He investigated, in their study, the levels of actual ethical identity disclosures compared to the expected ethical identity disclosures for 21 Islamic banks based in Bahrain and Malaysia for the period 2007-2011. For the purpose of this study, content analysis was employed to code the CSR information and put it onto various themes based on the criteria of coding employed by Haniffa and Hudaib (2007). Based on Ethical Identity Index, social disclosures in all Islamic banks, in the study, falls significantly short of public expectations and the standards set by the regulators. Islamic banks disclose more information regarding debtor, board of directors and top management dimension, while environmental issues the least popular theme in this study. In general, this study was a good effort to overcome the limitations of a number of previous studies that tried to examine CSR reporting from Islamic banking perspective. Those studies either look at a few number of Islamic banks in only one country or they look at a short period to draw conclusions on all Islamic banks. However, the authors of this paper did not provide any justifications for choosing Islamic banks based only in Bahrain and Malaysia.

Moreover, Kamla and Rammal (2013) conducted an investigation into the social reporting with special emphasis on social justice in 19 selected Islamic banks from different parts all over the world. They used content analysis to describe the presence and the absence of the social justice themes in the annual reports of Islamic banks. They also employed immanent critique to explore if claims of Islamic banks regarding their adherence to Islamic Sharia were supported by actual activities or not. The study conclude that although Islamic banks claim that they adhere to Islamic Sharia, CSR disclosures of Islamic banks need more detailed information regarding initiatives 
or schemes which aimed to eradicate poverty and improve social justice.

Kamla (2007) also conducted an investigation into the social reporting in selected Arab countries by means of criticizing the accountability of business through postcolonial perspectives. The aim of her study was to unveil how specifically Syria and Arab companies, in general, are enhancing and raising the sustainability after being influenced by Western accounting systems, owing largely to being colonised. Content analysis was employed so that to enable a critical examination of the volume, quality and nature of CSR practices in the annual reports of 68 companies from Syria, Jordan, Egypt and GCC countries. As a result of colonisation, she showed how companies had emphasised on the financial dimensions rather than social dimensions and business activities which contradict the Islamic Sharia. However, both studies (Kamla \& Rammal, 2013; Kamla, 2007) only look at one year, extending to more years would give greater insights because CSR disclosures evolve over time either because of a learning effect or because there are external drivers of CSR disclosures that are changing over time. Additionally, extending to more years would assist to enhance our understanding of the phenomenon.

Additionally, Belal et al. (2011) conducted a longitudinal study of the annual reports of one Islamic bank based in Bangladesh, Islamic Bank Bangladesh Limited (IBBL), for the period 1983-2009. Using content analysis to measure the level of CSR information disclosed by IBBL. According to content analysis evidence, there is an overall rise in the CSR disclosures of IBBL over the study period and the most popular themes are community involvement, charity and Sharia awareness respectively. However, this research just focused on a single case study; one Islamic Bank in Bangladesh. Thus, the findings of this study might not be generalized as a common trend in all of the Islamic banks.

Aribi and Gao (2010) conducted a comparison study between Islamic financial institutions and conventional ones based in Gulf Cooperation Council (GCC) countries in order to investigate the influence of Islam on CSR disclosures. For this objective, content analysis was employed to explore CSR disclosure in both groups of Financial Institutions. The findings of the study indicate that Islamic financial institutions disclosed more CSR information than conventional ones. Nevertheless, the differences between the two groups of financial institutions were largely due to some religious themes such as Sharia supervisory board reports, the Zakat and charity donation, and free interest loan. Although the study investigated a sample of 42 financial institutions based in GCC countries, the study, however only looked at only one fiscal year of 2004. Therefore, these findings might be better and give greater insights if their study covers a lot of time.

The study of Maali et al. (2006), Haniffa, and Hudaib (2007) are considered the early attempts to explore the influence of Islam on CSR reporting. The work of Maali et al. (2006) was one of the early attempts to develop a benchmark of social disclosures to Islamic Sharia. This benchmark was based on three key Islamic principles which are accountability, social justice, and ownership. In this study, content analysis was employed to compare the quantity of CSR disclosures among 29 selected Islamic banks from 16 countries all over the world against the benchmark. Their study, however, found that social reporting made by Islamic banks falls considerably short of their expectations. Moreover, this study found that Islamic banks which are not subject to Zakat disclose less social responsibility information compared to Islamic banks which are required to pay Zakat.

While Maali et al. (2006) only looks at one fiscal year of 2000, the work of Haniffa and Hudaib (2007) covered a three- year period. They conducted a longitudinal study of the annual reports of 7 selected Islamic banks based in GCC countries. They argued that Islamic banks are expected to have an ethical identity due to religious nature. From them, Islamic banks do not tend to emphasise on profit and non-social dimension as much as they do in conventional banks. Islamic banks, in their view, need to assist stakeholders by disclosing some information that helps them to make economic decisions. Using an ethical identity index they found that six out of seven banks suffer from disparity between the communicated and ideal ethical disclosures, whereas only one Islamic bank out of seven surveyed was above average.

However, from the studies conducted on the extent of CSR information in the annual reports, it was discovered that they were scarce and limited. Moreover, no one study conducted an investigation into the CSR reporting in Kuwait. Min addition, apart from the work of Aribi and Gao (2010), there was no study conducted a comparison study between Islamic banks and conventional ones regarding the differences in CSR reporting. Thus, the knowledge derived from the current study would shed some light on how to create a better accountability and transparency especially among the two groups of banks operating in Kuwait. Furthermore, examining CSR reporting from the standpoint of an emerging market such as Kuwait would contribute to a better understanding of social accounting problems.

\section{Sample and Research Methods}

Sixteen annual reports from 2007 to 2009, representing six Kuwaiti banks, 3 Islamic and 3 conventional ones, 
were examined in order to analyse the CSR reporting practices of these banks. Corporate annual reports are not the only means by which firms communicate social and environmental information. Banks may use different means such as websites, magazines and stand-alone reports by which firms can disclose detailed information on CSR (Maali et al., 2006). However, Gray et al. (1995b) pointed out that the annual report was a very important source of information because it is systematically produced, as well as it is central to the firms to build their own external image. Furthermore, the annual report provides credible information, which helps to strengthen the findings (Unerman, 2000).

To measure and compare the quantity of CSR information among the selected samples of banks, a content analysis was conducted. Content analysis is the most frequently employed method to evaluate CSR disclosure (Milne \& Adler, 1999). It has been widely employed in social accounting research and CSR literature (Gray et al., 1995; Guthrie \& Parker, 1990; Maali et al., 2006; Kamla \& Rammal, 2013; Kamla, 2007). Content analysis can be used to extract information from a broad range of communication media (Morris, 1994). Various units of a content analysis can be used including number of words, number of sentences and proportion of pages to measure the volume of CSR disclosure (Unerman, 2000). However, there are some advantages to using sentences as a unit of analysis because they are very easy to identify (Ingram \& Frazier, 1980). Thus, the use of sentences as a recording unit will increase the reliability of content analysis.

Moreover, according to Vourvachis (2007), there are five types of context in content analysis. Thus, units can be categorized as physical, syntactical, categorical, propositional, and thematic. However, the categorical context has more relevance for CSR research and is the most frequently used. The purpose of categories of analysis is to assist in analyzing the recording unit content in each sampling unit. Thus, this study will use the categorical context - positive vs. negative, substantive vs. symbolic-and the thematic context of marketplace, workplace, community, and environment issues in order to facilitate the content analysis of the annual reports of the two groups of banks. It is worth mentioning that, as not all the selected banks are based in Kuwait, the distinction between voluntary and mandatory CSR will be considered in this study because banks are not required to disclose CSR information in Kuwait.

This study measures and compares the CSR information in the annual reports over a three-year period of three Islamic banks, namely: Kuwait Finance House (KFH), Kuwait International Bank (KIB) and Boubyan Bank (BB). In addition to the three Islamic banks, the study examines CSR information in three conventional banks as well, namely: National Banks of Kuwait (NBK), Gulf Bank (GB) and Commercial Bank of Kuwait (CBK).

\section{Empirical Results}

\subsection{Thematic Context Findings}

A total of 16 annual reports over the three years, representing six Kuwaiti banks, 3 Islamic and 3 conventional banks, were analyzed using content analysis. The overall level of CSR disclosure made by both the Islamic and the conventional banks is presented in Table 1. Over the three-year period (2007-2009), Table 1 shows that the 16 annual reports contain some social disclosures. Furthermore, Table 1 shows that all selected banks made some CSR information under each of the three categories of marketplace, workplace, and community throughout 2007, 2008, and 2009. A further theme, the environment, was mentioned only by the conventional bank (NBK \& CBK). Moreover, as shown in Table 1, the total CSR information over the three years indicates a high priority to marketplace information, and a low priority given to environmental disclosures. Additionally, the maximum number of disclosure was undertaken in 2008 at 80 sentences by the National Bank of Kuwait (NBK), whilst the minimum amount of CSR information was in 2009 at 13 sentences by the Gulf Bank (GB).

The Islamic banks in this study disclosed less CSR information than the conventional banks, with an average level of 42 disclosures sentences noted for the Islamic banks as compared with 51.5 for the conventional banks. This finding might suggest that conventional banks operating in Kuwait concern themselves with pursuing ethical values more than the Islamic banks, which can merely claim that they comply with Islamic Sharia. Furthermore, it is noticeable that the CSR information disclosed by Islamic banks (KFH \& BB) tended to decline over time. On the other hand, the conventional bank (NBK) increased its disclosures regarding CSR information during the financial crisis of 2008, mainly in the themes of marketplace and community. It is worth mentioning that the conventional banks, disclosed more CSR information during the financial crisis than did the Islamic banks. The number of sentences disclosed by conventional banks during the financial crisis of 2008 was 167 compared with 121 by Islamic banks. This might be because the financial crisis mainly affected only conventional banks. Islamic banks do not deal in interest rates, which are prohibited in Islam, and thus Islamic banks were less affected by the financial crisis and therefore did not disclose more CSR. 
Table 1. Total Number of CSR disclosure Sentences

\begin{tabular}{llllllllllll}
\hline \multicolumn{1}{l}{ Panel A: Islamic Banks } & KFH & \multicolumn{1}{c}{ BB } & \multicolumn{1}{c}{ KIB } & & & & Total & Mean \\
\hline Year & 2007 & 2008 & 2009 & 2007 & 2008 & 2009 & 2007 & 2008 & 2009 & & \\
Marketplace & 33 & 19 & 15 & 23 & 21 & 12 & NA & 26 & 31 & 180 & 22.5 \\
Workplace & 9 & 6 & 3 & 12 & 10 & 7 & NA & 16 & 13 & 76 & 9.5 \\
Community & 19 & 11 & 16 & 7 & 10 & 10 & NA & 2 & 7 & 82 & 10 \\
Environment & 0 & 0 & 0 & 0 & 0 & 0 & NA & 0 & 0 & 0 & 0 \\
Total & 61 & 36 & 34 & 42 & 41 & 29 & NA & 44 & 51 & 338 & 42 \\
\hline Panel B: Conventional Banks & & & & & & & & & \\
\hline \multicolumn{1}{l}{} & NBK & & & CBK & & & GB & & & Total & Mean \\
\hline Year & 2007 & 2008 & 2009 & 2007 & 2008 & 2009 & 2007 & 2008 & 2009 & & \\
Marketplace & 43 & 49 & 36 & NA & 34 & 25 & 27 & 8 & 7 & 229 & 28.5 \\
Workplace & 12 & 8 & 6 & NA & 17 & 16 & 5 & 4 & 4 & 72 & 9 \\
Community & 14 & 20 & 17 & NA & 21 & 20 & 8 & 2 & 2 & 104 & 13 \\
Environment & 1 & 3 & 2 & NA & 1 & 1 & 0 & 0 & 0 & 8 & 1 \\
Total & 70 & 80 & 61 & NA & 73 & 62 & 40 & 14 & 13 & 413 & 51.5 \\
\hline
\end{tabular}

The marketplace theme, in this study, includes customer satisfaction, meeting customer needs, insolvent client's policy, developing and innovating new products, quality of products and services, and customer services. As shown on Table 1, all Islamic and conventional banks' CSR information focused mostly on the marketplace over the three- year period. This observation is further supported by the total sentences related to marketplace, 180 sentences with an average of 22.5 per annual report for Islamic banks, and 229 sentences with an average of 28.5 per annual report for conventional banks. Under this theme, the high number of disclosure sentences might be justified, since clients connect directly with banks through dealing in their products and services and thus have a significant influence on the banks' reputation (Aribi, 2009). These findings on the marketplace and CSRD information overall were expected because Islamic banks claim they comply with Islamic Sharia that emphasize the full right of Muslims to be well-informed about any changes of operations in the company.

Additional insight can be obtained from Table 1. The employee theme is considered the most popular theme and the main interest of employees and ethical shareholders (Adams et al., 1995). This theme includes employee data, equal opportunity, training and development, end services indemnity and pension, appreciation and thanks to employees, consultation with employee and nationalizing of workforce. As shown in Table 1, both the Islamic and conventional banks disclosed less CSR information regarding employees. This theme received the second lowest score for both types of bank. In general, there are no differences in the level of CSR information made by the two groups of banks. However, Islamic banks reported the largest amount of CSR information, with a total number of 76 sentences and an average of 9.5 per annual report. In contrast, the total number of sentence disclosed by conventional banks was 72 with an average of 9 per annual report. The findings of the employee theme are completely inconsistent with both Islamic Sharia and western literature.

The community disclosures, in the current paper, include community investment, contribution to national economy, education and health support, consultation with community, social activities support and philanthropy (charities, Zakat \& donation). However, Sharia Supervisory Board Report (SSBR) is relevant only to Islamic banks and, consequently, any CSR disclosures about SSBR are excluded in this study. It is evident that the average amount of CSRD information for the community theme is lower for the Islamic banks as compared with the conventional banks. However, for both banks, this theme received the second highest score, 10 for Islamic banks and 13 for conventional banks. From table 1, also the largest Islamic bank, KFH, did not increase the level of community information disclosed during the financial crisis of 2008, whereas this type of information increased considerably for the biggest conventional bank (NBK). This might be because conventional banks operating in Kuwait pay more attention to showing their interest in ethical values and Arab Islamic social issues.

An environmental disclosure, in this study, is divided into five categories. This theme includes environmental 
policy, pollution and recycle, energy, sponsoring environmental activities and others. In the current paper, neither the Islamic nor the conventional banks disclosed much information regarding environmental issues, especially Islamic banks, which did not mention any environment information in their annual reports for 2007, 2008 and 2009. The conventional bank (NBK), on the other hand, mentioned the environmental issues once in its 2007 annual report, three times in its 2008 annual report and twice in the 2009 report. The other conventional bank (CBK) mentioned once in each year of 2008 and 2009. There are two explanations for low level of environment disclosure. First, the banking sector does not have vast environmental impacts and, second, that the environment is not one of the major concern of Arab countries (Belal, 2000). The findings of environment theme are unsurprising, as they seem to be consistent with the results of several studies conducted in the context of developing countries. Although the protection of the environment is one of the principles of social responsibility in Islam and the increasing efforts of gulf countries to promote environment protection, it is still not one of the major concerns of the Arab countries.

\subsection{Categorical Context Analyses}

\subsubsection{Positive vs. Negative CSRD}

As shown on Table 2, the two types of banks did not disclose any negative information in their annual reports throughout 2007, 2008, and 2009, rather the disclosures of both banks tended to be positive. These results lend support to the finding of Campbell et al. (2003) that firms desire to disclose negative CSR information on their website or supplementary reports, rather than in their annual reports. Hence, both Islamic and conventional banks, over the three-year period, tried to reinforce their image by disclosing positive CSR information in their annual reports and negative CSR information in their stand-alone report or other reports. Moreover, it is worth mentioning that this study is the only study using the positive vs. negative distinction. It did not find any negative information in either banks' annual reports. This could be because such information might affect the banks' reputations and thus might decrease their profitability. The findings of positive and negative CSR information are not consistent with the Islamic concepts of full disclosure, truthfulness, and honesty in business that state that the Islamic Ummah (community) has the full right to be well informed about any changes of operations in a company (Al-Bukhari, 1997).

Table 2. Number of Positive, Negative Sentences

\begin{tabular}{|c|c|c|c|c|c|c|c|c|c|c|c|}
\hline \multicolumn{12}{|c|}{ Panel A: Islamic Banks } \\
\hline & \multicolumn{3}{|c|}{ KFH } & \multicolumn{3}{|c|}{ BB } & \multicolumn{3}{|c|}{ KIB } & \multirow[t]{2}{*}{ Total } & \multirow[t]{2}{*}{ Mean } \\
\hline Year & 2007 & 2008 & 2009 & 2007 & 2008 & 2009 & 2007 & 2008 & 2009 & & \\
\hline Positive & 61 & 36 & 34 & 42 & 41 & 29 & NA & 44 & 51 & 338 & 42 \\
\hline Negative & 0 & 0 & 0 & 0 & 0 & 0 & NA & 0 & 0 & 0 & 0 \\
\hline Total & 61 & 36 & 34 & 42 & 41 & 29 & NA & 51 & 51 & 338 & 42 \\
\hline \multicolumn{12}{|c|}{ Panel B: Conventional Banks } \\
\hline & & NBK & & & CBK & & & GB & & Total & Mean \\
\hline Year & 2007 & 2008 & 2009 & 2007 & 2008 & 2009 & 2007 & 2008 & 2009 & & \\
\hline Positive & 70 & 80 & 61 & NA & 73 & 62 & 40 & 14 & 13 & 413 & 51.5 \\
\hline Negative & 0 & 0 & 0 & NA & 0 & 0 & 0 & 0 & 0 & 0 & 0 \\
\hline Total & 70 & 80 & 61 & NA & 73 & 62 & 40 & 14 & 13 & 413 & 51.5 \\
\hline
\end{tabular}

Regarding positive disclosures, Table 2 shows that the average number of positive CSR information disclosed by the Islamic banks was 42 as compared with 51.5 by the conventional banks. Furthermore, positive CSR information of the Islamic banks (KFH \& BB) tended to be declining over the three-year period, even during the financial crisis in 2008. On the other hand, although the conventional banks disclosed more positive information in each year than did the Islamic banks, the conventional banks NBK and CBK disclosed more positive information in 2008 than 2007 and 2009. This might be due to the effects of the 2008 financial crisis on the banking sector. 


\subsubsection{Substantive vs. Symbolic}

The results of substantive vs. symbolic CSR information are consistent with previous findings regarding positive vs. negative CSRD in 2007, 2008 and 2009. The increase in substantive CSR information shown in table 3 might be due to banks attempting to substantively address threats as they are known in legitimacy theory (Campbell et al., 2003).

Table 3. Number of Substantive and Symbolic Sentences

\begin{tabular}{llllllllllll}
\hline \multicolumn{1}{l}{ Panel A: Islamic Banks } & \multicolumn{1}{c}{ KFH } & \multicolumn{1}{c}{ BB } & & \multicolumn{1}{c}{ KIB } & & Total & Mean \\
\hline Year & 2007 & 2008 & 2009 & 2007 & 2008 & 2009 & 2007 & 2008 & 2009 & & \\
Substantive & 40 & 27 & 26 & 20 & 20 & 16 & NA & 25 & 29 & 230 & 25 \\
Symbolic & 21 & 9 & 8 & 22 & 21 & 13 & NA & 19 & 22 & 135 & 17 \\
Total & 61 & 36 & 34 & 42 & 41 & 29 & NA & 44 & 51 & 338 & 42 \\
\hline Panel B: Conventional & Banks & & & & & & & & & & \\
\hline \multicolumn{1}{l}{} & NBK & & & CBK & & & GB & & & Total & Mean \\
\hline Year & 2007 & 2008 & 2009 & 2007 & 2008 & 2009 & 2007 & 2008 & 2009 & & \\
Substantive & 44 & 52 & 39 & NA & 42 & 31 & 18 & 9 & 5 & 240 & 30 \\
Symbolic & 26 & 28 & 22 & NA & 31 & 31 & 22 & 5 & 8 & 173 & 21.5 \\
Total & 70 & 80 & 61 & NA & 73 & 62 & 40 & 14 & 13 & 413 & 51.5 \\
\hline
\end{tabular}

Table 3 presents the findings for the substantive vs. symbolic distinction for the Islamic and the conventional banks. The overall level of both substantive and symbolic information disclosed was lower for the Islamic banks than for the conventional banks during the three years studied. The average number of substantive sentences made by Islamic banks and the conventional banks were 25 and 30 respectively, whilst for symbolic sentences, it was 17 for the Islamic banks, and 21 for the conventional banks. These findings show a significant difference between the two group of banks and support previous studies. The high number of substantive sentences made by the conventional bank might represent an ethics-oriented organization attempting to address increased stakeholder expectations in a substantive way (Vourvachis, 2009). Moreover, the level of substantive CSR information, in 2009, made by the conventional banks fell by nearly $30 \%$, whereas its level of symbolic CSR information appeared to be stable. This might be because the conventional banks operating in Kuwait recovered from the 2008 financial crisis.

On the other hand, substantive CSR information made by Islamic banks, KFH and BB, declined over time, even during the financial crisis, from 40 to 26 for KFH and from 20 to 16 for BB in their annual reports. The other Islamic bank, KIB, increased their substantive CSRD from 25 in 2008 to 29 in 2009. Additionally, the level of symbolic CSR information disclosed by the Islamic banks fell from 21 to 8 for KFH and from 22 to 13 for BB. The main reason for these decreases in disclosing substantive CSR information might be because the Islamic banks had not been affected by the 2008 financial crisis to the same degree as the conventional bank. Thus, the quantitative findings for the Islamic banks do not support the legitimacy theory, whereas for conventional bank, they do.

\section{Discussion}

The main findings of the quantitative content analysis indicate that both the Islamic banks and conventional banks disclosed some CSR information throughout 2007, 2008 and 2009. However, despite Islamic Sharia that calls for and emphasizes ethical business behaviour, the Islamic banks disclosed less CSR information as compared with the conventional banks, with an average level of 42 sentences made by the Islamic bank as compared with 51.5 made by the conventional banks. Even during and following the financial crisis of 2008, the Islamic banks did not disclose more CSR information. This might be because the Islamic banks were less affected by the financial crisis of 2008 than were the conventional banks due largely to Islamic banks not dealing in interest rates, which are prohibited in Islam. On the contrary, the conventional banks increased its overall CSR information during and following the financial crisis in 2008. Thus, the findings for the Islamic banks do not 
support legitimacy theory, whereas the findings for the conventional banks do. Moreover, this might also be because conventional banks operating in Kuwait may pay more attention to clients and make a greater effort to show their interest in ethical values.

Furthermore, one of the main findings of this current study is that the two types of banks tended to be customer focused. For example, for both groups of banks, the marketplace theme received the highest number of sentences, 180 sentences for Islamic banks and 229 sentences for conventional banks. In contrast to the marketplace findings, there was no CSR information regarding environmental issues made by the Islamic banks throughout the three years studied, and the conventional banks paid little attention to environmental issues. This might be because both groups of banks are operating in a developing country, the state of Kuwait, and thus environmental issues are not one of the major concerns. This finding might be attributed to the fact that banking sector generally does not have a huge environmental impact.

In addition, although the Islamic banks provided Zakat information and a Sharia Supervisory Board Report (SSBR) in their annual reports in order to confirm that it follows Islamic Sharia law, the Islamic banks did not disclose detailed information about Qard Hassan and Sadaqa in their annual reports. On the other hand, conventional banks incorporated Islamic values into their operations to erode any impact of Islamic social pressures. This was further indicated by the level of disclosure noted relating to the community theme, in which conventional banks recorded 104 sentences as compared with 82 for Islamic banks. Furthermore, both groups of banks did not disclose any negative information in their annual reports throughout 2007, 2008, and 2009. Instead, the disclosures of both type of banks tended to be positive. This might be because negative information may affect the reputation of banks and thus decrease their profitability. Moreover, negative information cannot be disclosed in the Arab world owing perhaps to having a negative impact upon banks. Whereas this can also influence institutions negatively in the Western world, negative information is nonetheless announced to show the level of honesty and to raise believability. Additionally, the results of the analysis of substantive vs. symbolic CSR information were not a surprise because they are consistent with previous findings of positive vs. negative information for the years 2007, 2008, and 2009.

\section{Conclusion}

The objective of this study is to explore the differences in CSR reporting between two types of banks by analysing the annual reports of six Kuwaiti banks, 3 Islamic and 3 conventional banks over a three-year period. A total of 16 annual reports are examined to analyse the CSR reporting practices of banks using content analysis.

The findings of this study contribute to the CSR literature by detailing the differences and similarities between Islamic and conventional banks with respect to the volume, the types of CSR information and the kinds of news disclosed by the two groups of banks. Examining CSR reporting from the standpoint of an emerging market such as Kuwait would contribute to a better understanding of social accounting problems. In addition, examining the CSR reporting practices of Islamic banks is likely to provide new insight into the influence of Islam on CSR disclosure. Examining the CSR reporting practices of conventional banks operating in a Muslim country would also provide new insight into the influence of Islamic and Arab culture on CSR reporting of conventional banks operating on the western system.

Moreover, this study is the only study, to the best of our knowledge that does not find negative information disclosed by the two types of banks. It also contributes to the field of CSR by looking at legitimacy theories where Islamic banks did not react, whilst conventional ones did. Additionally, the current study reviewed and used two context distinctions that are not frequently used in CSR studies-substantive vs. symbolic and positive vs. negative - after customizing them to meet the needs of this study.

Due to time limits, this study could not pursue a larger sample of banks based in the state of Kuwait. As such, future research might wish to develop a larger sample of Islamic and based in all parts of the Gulf Cooperation Council (GCC). In addition, this study only compares Islamic banks and conventional ones. In other words, the comparison in this study is only between Islamic teachings and the perspective of Western countries. Future research might compare Buddhist and Chinese cultural values in relation to CSR in order to provide a broader international perspective on CSR issues. Moreover, it would be interesting to investigate CSR in Islamic and conventional banks in other countries such as those operating in the Western countries. Finally, other methods such as surveys and interviews were not considered in this study. In future researches, such methods might be useful to examine CSR reporting practice in Islamic and conventional banks based in the Gulf Cooperation Council (GCC) countries. 


\section{References}

Adams, C., Coutts, A., \& Harte, G. (1995). Corporate Equal Opportunities (non) Disclosure. British Accounting Review, 27(2), 87-108. https://doi.org/10.1006/bare.1994.0005

Al-Bukhari, M. (1997). Imam Bukhari's Book of Muslim Morals and Manners. Alexandria: Al-Saadawi Publications.

AlKulaib, Y. A., Almudhaf, F. W., \& Al-Jassar, S. (2013). The Banking Industry during an Extended Financial Crisis: An Empirical Assessment of Kuwait Banks. Academy of Banking Studies Journal, 12(1), 61-73.

Aribi , Z. (2010). Corporate social responsibility disclosure:A comparison between Islamic and conventional financial institutions. Journal of Financial Reporting and Accounting, 8(2), 272-291. https://doi.org/10.1108/19852511011088352.

Badawi, M. A. Z (1979). Zakat and Social Justice. English translation of the Book: Kitab ul Amwal by Imam Abu Abaid Al-Qasim. London: The Islamic Council of Europe.

Bebbington, J., Larrinaga, C., \& Moneva, J. (2008). Corporate social reporting and reputation risk management. Accounting, Auditing \& Accountability Journal, $21(3), \quad 337-361$. https://doi.org/10.1108/09513570810863932.

Belal, A. (2000). Environmental Corporate Disclosure in Developing Countries: Empirical Evidence from Bangladesh. Eco-Managerial and Auditing Journal, https://doi.org/10.1002/1099-0925(200009)7:3<114::AID-EMA131>3.0.CO;2-E

Belal, A., Abdelsalam, O., \& Nizamee, S. (2011). A Longitudinal Case Study of Social Reporting in Islami Bank Bangladesh Limited. Paper presented at the British Accounting and Finance Association (BAFA) Conference 2011

Brewer, R., \& Salamé, R. (2009). Islamic Finance Qualification. s.l.: Chartered Institute for Securities and Investment and Ecole Supérieure des Affaires (3th ed.).

Campbell, D., Craven, B., \& Shrives, P. (2003). Voluntary Social Reporting in Three FTSE Sectors: A Comment on Perception and Legitimacy. Accounting, Auditing and Accountability Journal, 16(4), 558-581. https://doi.org/10.1108/09513570310492308

CapitalStandards. (2011). Kuwait Banking Industry. Retrieved July 15, 2012, from http://www.capstandards.com/KuwaitBankingIndustry(Update)_March_2011.pdf

CapitalStandards. (2013). Kuwait Banking Sector. Retrieved July 15, 2014, from http://www.capstandards.com/PDF/Kuwait\%20Banking\%20Sector\%2015-05-2013.pdf

Gray, R., Kouhy, R., \& Lavers, S. (1995). Corporate Social and Environmental Reporting: A Review of the Literature and a Longitudinal Study of UK Disclosure. Accounting, Auditing and Accountability Journal, 8(2), 47-77. https://doi.org/10.1108/09513579510146996

Gray, R., Owen, D., \& Maunders, K. (1987). Corporate Social Reporting Accounting and Accountability. Hemel Hempstead: Prentice Hall.

Haniffa, R., \& Hudaib, M. (2007). Exploring the ethical identity of Islamic banks via communication in annual reports. Journal of Business Ethics, 76, 97-116. https://doi.org/10.1007/s10551-006-9272-5

Hassan, M. (1992). The Tawhidic Approach in Management and Administration: Concepts, Principles and an Alternative Model. Kuala Lumpur: National Institute of Public Administration.

Ingram, R., \& Frazier, K. (1980). Environmental performance and corporate disclosure. Journal of Accounting Research, 18(2), 614-622, doi.org/10.2307/2490597.

Kamla, R. (2005). Social Accounting in a Selection of Arab Countries: Critical and Postcolonial Perspectives (Unpublished Ph.D. Thesis). Heriot-Watt University, UK.

Kamla, R. (2007). Critically appreciating social accounting and reporting in the Arab Middle East: A postcolonial perspective. Advances in International Accounting, 20, 105-177.

Kamla, R., \& Rammal, H. (2013). Social reporting by Islamic banks: Does social justice matter?. Accounting, Auditing \& Accountability Journal, 26(6), 911-945. https://doi.org/10.1108/AAAJ-03-2013-1268.

Lewis, M. (2001). Islam and Accounting. Accounting Forum, 25(2), $103-127$. https://doi.org/10.1111/1467-6303.00058. 
Maali, B., Casson, P., \& Napier, C. (2006). Social Reporting by Islamic Banks. Abacus, 42(2), 266-289.

Mawdudi, S. (1988). Towards Understanding the Quran: Vol. $l$ (Translated and edited by Zafar Ishag Ansari). Leicester, UK: The Islamic Foundation.

Milne, M., \& Adler, R. (1999). Exploring the Reliability of Social and Environmental Disclosures Content Analysis. Accounting, Auditing \& Accountability Journal, 12(2), 237-256 https://doi.org/10.1108/09513579910270138

Mohammed, J. (2007). Corporate Social Responsibility in Islam (Unpublished Ph.D. Thesis) Auckland University of technology, New Zealand.

Morris, R. (1994). Computerized Content Analysis in Management Research: A Demonstration of Advantages and Limitations. Journal of Management, 2(4), 903-931. https://doi.org/10.1016/0149-2063(94)90035-3

Mukhazir, M., Muhammad, R., \& Noordin, K. (2006). Corporate Social Responsibility Disclosure: A Tawhidic Approach. Journal of Shariah, 14(1), 125-142.

Quran. (1410 H). The Holy Quran, Mushaf Al-Madinah An-Nabawiayah the Holy Qur'an: English Translation of Meanings and Commentary. Mecca: King Fahd Holy Qur'an printing Complex.

Rahman, R., Danbatta, B., \& Saimi, N. (2014). Corporate Ethical Identity Disclosures: The Perceived, the Publicized and the Applied in Islamic Banks. International Journal of Trade, Economics and Finance, 5(2), 199-203. https://doi.org/10.7763/IJTEF.2014.V5.371

Sairally, B. (2006). A Study in the Corporate Social Responsibility of Islamic Financial Intuitions: Learning from the Experiences of Socially Responsible Financial Institutions in the UK (Unpublished Ph.D. Thesis). Loughbourgh University, England.

Vourvachis, P. (2007). On the Use of Content Analysis (CA) in Corporate Social Reporting (CSR): Revisiting the Debate on the Units of Analysis and the Ways to Define Them. Paper presented at the British Accounting Association Annual Conference, Royal Holloway.

Vourvachis, P. (2008). In Search of Explanations for Corporate Social Reporting (CSR): An Attempt to Revisit Legitimacy Theory. Kingston Business School Working paper series No 16, May.

Vourvachis, P. (2009). In Search of Explanations for Corporate Social (Unpublished Ph.D. Thesis). Kingston University, London.

\section{Copyrights}

Copyright for this article is retained by the author(s), with first publication rights granted to the journal.

This is an open-access article distributed under the terms and conditions of the Creative Commons Attribution license (http://creativecommons.org/licenses/by/4.0/). 